\title{
Measurement of serum C-reactive protein levels in early second trimester as a predictor of preterm delivery
}

\author{
Sujatha Senthil, S. Dhamayanthi*
}

Department of Obstetrics and Gynecology, Tirunelveli Medical College, Tirunelveli, Tamil Nadu, India

Received: 17 September 2019

Accepted: 25 October 2019

\section{*Correspondence:}

Dr. S. Dhamayanthi,

E-mail: dhamayanthisethuramalingam@gmail.com

Copyright: (C) the author(s), publisher and licensee Medip Academy. This is an open-access article distributed under the terms of the Creative Commons Attribution Non-Commercial License, which permits unrestricted non-commercial use, distribution, and reproduction in any medium, provided the original work is properly cited.

\begin{abstract}
Background: Preterm labour is the leading cause of perinatal morbidity and mortality. Infection plays a major role in preterm labour. Elevation of CRP, an inflammatory biomarker has been associated with spontaneous preterm birth. This study was aimed at evaluating the relation of C-reactive protein in early second trimester with preterm labour and neonatal morbidity.

Methods: It is a prospective cohort study, 200 pregnant women of singleton pregnancy between the gestational age of 14 to 20 weeks were enrolled. After detailed history taking, maternal serum CRP levels were estimated by ELISA method. These women were divided into two groups according to CRP levels. Incidence of preterm delivery and incidence of neonatal morbidity was compared in both groups to ascertain if measured maternal CRP levels has any association with preterm labour and neonatal morbidity.

Results: In this study 42 patients $(21 \%)$ had preterm delivery. Of these 30 patients had CRP > 1.5mg/dl; 12 had CRP $<1.5 \mathrm{mg} / \mathrm{dl}$. In CRP increased group, 30 patients $(57.7 \%)$ delivered preterm, 22 patients $(42.3 \%)$ had term. It was found that increased levels of maternal serum CRP in early pregnancy were associated with increased incidence of preterm delivery. According to this study if the CRP value 1.5 the sensitivity will be $71.4 \%$ and specificity will be $86 \%$ to predict the preterm. Of the total 42 preterm babies, 1 from Group A (8.3\%) and 12 from Group B (40\%) developed sepsis. So increased CRP has association with neonatal sepsis.

Conclusions: Elevated maternal serum CRP concentration in early second trimester was associated with increased incidence of preterm delivery and showed a positive correlation with neonatal sepsis.
\end{abstract}

Keywords: C-reactive protein, Early second trimester, Enzyme-linked immunosorbent assay, Infections, Neonatal sepsis, Preterm labour

\section{INTRODUCTION}

Preterm labour is defined as one where the labour starts before the $37^{\text {th }}$ completed weeks or $<259$ days, counting from the last day of menstrual period. The lower limit of gestation is not uniformly defined; whereas in developed countries it has been brought down to 20 weeks, in developing countries it is 28 weeks. It is the leading cause of perinatal morbidity and mortality. Babies who survive are also at higher risk of neurological disability, further breathing feeding, visual and hearing problems. In India, out of 27 million babies born every year (2010 data), 3.5 million babies born are premature. ${ }^{1}$

In order to address the problem of preterm delivery, identification of those at risk remains an important step. Several strategies have been suggested, including risk scoring systems, biochemical markers of inflammation, and screening for various infections. ${ }^{2,3}$ It is important to evaluate these potential predictors alone or in 
combination in the asymptomatic population and consider the economic impact of these screening tests.

C-reactive protein (CRP) is an acute-phase reactant, which often rises significantly following an inflammatory process, with maximum concentration 48 hours after stimulation and a half-life of 8-9 hours and is certainly at the same time independent of pregnancy. ${ }^{4,5}$ CRP is produced in the liver and is present in normal nonpregnant individuals at a concentration ranging from 0.6 to $0.8 \mathrm{mg} / \mathrm{dl}$ C-reactive protein (CRP) is a sensitive marker of inflammation that remains stable in serum. ${ }^{4,6}$ Elevated concentrations of CRP in peripheral circulation has been associated with the presence of intrauterine infection. $^{7}$ The maternal concentration of CRP has been studied as an aid to diagnose subclinical infections. 40 to 50 percent of preterm labour is due to infections.

Recently, elevated levels of CRP measured during gestation have been linked to adverse pregnancy outcomes such as preeclampsia and intrauterine growth restriction. ${ }^{8}$ To our knowledge, there are only two studies of the relation between CRP levels in maternal circulation during the second trimester of pregnancy and risk of preterm delivery. These studies showed contradictory results. Hvilsom et al, reported a significant association of elevated serum CRP levels with a nearly twofold increased risk of delivery before 37 weeks gestation. ${ }^{9}$ Ghezzi et al, found no relation between circulating CRP levels and preterm delivery. ${ }^{10}$ In this study the association between maternal serum CRP in early second trimester and subsequent preterm delivery among a cohort of singleton pregnant women was studied.

\section{METHODS}

It is a prospective cohort study in 200 pregnant women attending outpatient department in the department of obstetrics and gynaecology, Tirunelveli Medical College, Tamil Nadu, from August 2018 to August 2019 to determine whether elevated serum CRP in early second trimester as a predictor for preterm labour.

\section{Inclusion criteria}

- All cases of singleton gestation with gestational age between 14-20 weeks (by LMP and confirmed by ultrasound)

- Intact amniotic membranes.

\section{Exclusion criteria}

- Multiple gestation

- Pre-eclampsia

- Gestational diabetes mellitus

- Polyhydramnios

- History of pre-term labor in prior pregnancy

- Medical conditions like SLE, rheumatoid arthritis, $\mathrm{H} / \mathrm{O}$ recent bacterial or viral infections, heart disease
- Gestational age less than 13 weeks or more than 20 completed weeks

- Women not sure of LMP and not having a dating scan.

After informed consent, pregnant women attending the antenatal clinic according to the inclusion and exclusion criteria were enrolled and the serum $\mathrm{C}$-reactive protein levels to be measured at GA of 14 to 20 weeks pregnancy and pregnant women were followed up to delivery and then they were allocated to preterm and non-preterm groups based on the GA at delivery.

Gestational age was calculated based on last menstrual period and confirmed by ultrasound report of 11-14 weeks. If both the LMP and USG EDD are within 14 days, gestational age is based on LMP, if > 14 days USG EDD can be taken into account. A detailed history regarding the maternal socioeconomic status, anthropometry, lifestyle habits, medical and surgical illness was taken.

Venous blood samples were obtained from the patient to measure serum c-reactive protein concentrations between 14- and 20-weeks' gestation. Samples were collected in a test tube without anticoagulant and allowed to clotted. Serum removed from the clot as soon as possible to avoid hemolysis and kept frozen until tested in the laboratory. The levels of C-Reactive protein measured through a quantitative highly sensitive immunoassay test (ELISA).

The reference value is $1.5 \mathrm{mg} / \mathrm{d} 111$. Thus, high maternal serum c-reactive protein in pregnancies were defined as those in which maternal serum level remained above $1.5 \mathrm{mg} / \mathrm{dl}$. In association between high maternal serum Creactive protein and preterm labour, the two outcome variables were tested using chi-square and significance reported at $\mathrm{P}<0.05$. The receiver operating characteristic curve was also used for statistical analysis.

The study group patients are divided into two groups as Group A and Group B depending upon CRP levels. The diagnosis of preterm delivery was made using ACOG guidelines. The women who delivered before 37 weeks gestational age were brought under preterm and > 37 weeks as term by using the detailed information collected during the time of delivery from the medical records concerned.

Neonatal outcome of all the babies were studied, 1 minute and 5-minute Apgar and neonatal complications like RDS, neonatal sepsis, intraventricular hemorrhage were noted. RDS were diagnosed based on clinical symptoms like tachypnea, grunting, subcostal retraction, cyanosis and $\mathrm{X}$ ray findings such as reticular granularity and air bronchogram. Neonatal sepsis used to present with diminished activity, poor sucking, apnea, bradycardia, temperature instability, vomiting, diarrhoea, abdominal distension, seizure and jaundice. Diagnosis is clinical and based on culture reports. 


\section{Statistical analysis}

Categorical variables were compared between groups using Chi-square test. For CRP, a receiver operating characteristic (ROC) curve analysis was used to establish the cut-off values that optimized the prediction of preterm labor. Sensitivity, specificity was then calculated. $\mathrm{P}$ values less than 0.05 were considered to indicate statistical significance.

\section{RESULTS}

\section{Distribution of term and preterm delivery}

In this study 42 patients (21\%) had preterm delivery and 158 patients $(79 \%)$ delivered in term (Table 1$)$.

Table 1: Distribution of term and preterm delivery.

\begin{tabular}{|lll|}
\hline Gestational age & Frequency & Percent \\
\hline$<37$ weeks & 42 & 21.0 \\
\hline$>37$ weeks & 158 & 79.0 \\
\hline Total & $\mathbf{2 0 0}$ & $\mathbf{1 0 0 . 0}$ \\
\hline
\end{tabular}

\section{Division of groups}

A total of 200 patients were included in the study, these patients were divided into two groups based on their serum CRP levels. A total of 52 (26\%) had CRP levels $>1.5 \mathrm{mg} / \mathrm{dl}$ belonged to Group B and 148 (74\%) had CRP level $<1.5 \mathrm{mg} / \mathrm{dl}$ as Group A (Table 2).
Table 2: Division of groups.

\begin{tabular}{|lll|}
\hline CRP group & No. of patients & Percent \\
\hline 0-1.5 Group A & 148 & 74 \\
\hline Above 1.5 Group B & 52 & 26 \\
\hline Total & $\mathbf{2 0 0}$ & $\mathbf{1 0 0 . 0}$ \\
\hline
\end{tabular}

\section{CRP levels and incidence of preterm delivery}

A total of 200 patients included in this study; 158 patients had $\mathrm{CRP}<1.5 \mathrm{mg} / \mathrm{dl}$; of these 136 patients (91.9\%) delivered term; 12 patients $(8.1 \%)$ had preterm delivery. Remaining 42 patients had CRP $>1.5$; of these 30 patients $(57.7 \%)$ delivered preterm, 22 patients $(42.3 \%)$ had term delivery. According to this study if the CRP value 1.5 the sensitivity will be $71.4 \%$ and specificity will be $86 \%$ to predict the preterm labour (Table 3, 4, 5, Figure 1).

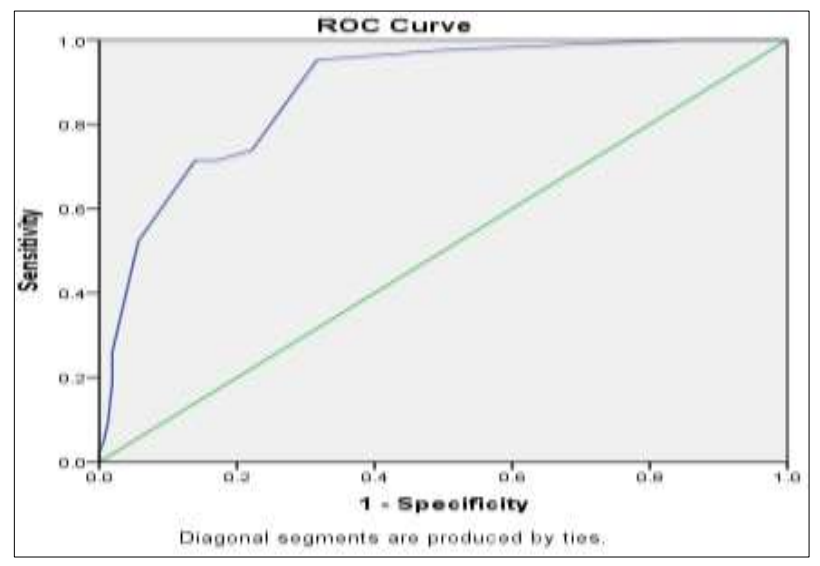

Figure 1: CRP ROC Curve

Table 3: CRP levels and incidence of preterm delivery.

\begin{tabular}{|lllll|}
\hline \multirow{2}{*}{ Gestational age } & & CRP group & & Total \\
\hline \multirow{2}{*}{$<37$ weeks } & Count & Group A (0-1.5) & Group B > 1.5 & 42 \\
\cline { 2 - 5 } & \%within CRP group & $8.1 \%$ & 30 & $21 \%$ \\
\hline \multirow{2}{*}{$>37$ weeks } & Count & 136 & $57.7 \%$ & 158 \\
\hline \multirow{2}{*}{ Total } & \%within CRP group & $91.9 \%$ & 22 & $79 \%$ \\
\cline { 2 - 6 } & Count & $\mathbf{1 4 8}$ & $42.3 \%$ & $\mathbf{2 0 0}$ \\
\cline { 2 - 6 } & \%within CRP group & $\mathbf{1 0 0 \%}$ & $\mathbf{5 2}$ & $\mathbf{1 0 0 \%}$ \\
\hline
\end{tabular}

Pearson Chi-Square $=57.026^{* *} \mathrm{P}<0.001$.

Table 4: Comparative statistical analysis of ROC curve of serum CRP.

\section{Area under the curve}

\begin{tabular}{|c|c|c|c|c|}
\hline \multirow{2}{*}{ Area } & \multirow{2}{*}{ Std. Error ${ }^{a}$} & \multirow{2}{*}{ Asymptotic Sig. ${ }^{b}$} & \multicolumn{2}{|c|}{ Asymptotic 95\% Confidence Interval } \\
\hline & & & Lower Bound & Upper Bound \\
\hline 0.880 & 0.027 & 0.000 & 0.827 & 0.932 \\
\hline
\end{tabular}

The test result variable(s): CRP has at least one tie between the positive actual state group and the negative actual state group.

Statistics may be biased. a. Under the nonparametric assumption; b. Null hypothesis: true area $=0.5$ 
Table 5: Diagnostic accuracy of serum CRP in predicting preterm delivery.

\begin{tabular}{|lll|}
\hline $\begin{array}{l}\text { Coordinates of the curve (CRP) } \\
\text { Serum CRP positive if } \\
\text { greater than or equal to }\end{array}$ & Sensitivity & Specificity \\
\hline 1.5 & 0.714 & 0.139 \\
\hline
\end{tabular}

If we select the CRP value is 1.5 then sensitivity will be

$71.4 \%$ with specificity will be $86 \%$ to predict the pre term.

\section{CRP and neonatal sepsis}

Of the total 42 preterm babies, 1 from Group A ( $8 \%)$ and 12 from Group B (40\%) developed sepsis and were treated with IV antibiotics. $\mathrm{P}<0.05$, hence there was statistically significant difference in development of neonatal sepsis between preterm infants of 2 groups. Infants born to increased CRP group, there is increased chance of neonatal sepsis (Table 6).

Table 6: CRP and neonatal sepsis in preterm infants.

\begin{tabular}{|llll|}
\hline CRP value Mg/dl & Neonatal sepsis (Number) & Normal preterm babies & Total preterm babies \\
\hline Group A $(0-1.5)$ & $1(8.3 \%)$ & 11 & 12 \\
\hline Group B $>1.5$ & $12(40 \%)$ & 18 & 30 \\
\hline Total & $\mathbf{1 3}$ & $\mathbf{2 9}$ & $\mathbf{4 2}$ \\
\hline
\end{tabular}

Chi-square statistic is 4.0218 . The $\mathrm{p}-$ value is $0.044917(<0.05)$.

\section{DISCUSSION}

CRP is an acute phase reactant protein synthesized primarily in liver cells in response to pro inflammatory cytokines including IL-6 and alpha TNF. C reactive protein in maternal peripheral circulation is associated with presence of intrauterine infection. ${ }^{7}$

In this study, 200 pregnant women of singleton pregnancy between the gestational age of 14 to 20 weeks were enrolled. After detailed history taking, maternal serum CRP levels were estimated by ELISA method. These women were divided into two groups according to CRP levels. Incidence of preterm delivery, mode of delivery was noted in both the groups. The incidence of neonatal morbidity was compared in both groups to ascertain if measured maternal CRP levels has any association with neonatal morbidity.

The mean age of the patients in this study 25 years. The mean gestational age was 16.5 weeks. The minimal gestational age was $14+1$ weeks and maximal was $19+3$ weeks. In this study 42 patients $(21 \%)$ had preterm delivery. Of these 30 patients had CRP > $1.5 \mathrm{mg} / \mathrm{dl} ; 12$ had CRP $<1.5 \mathrm{mg} / \mathrm{dl}$. In CRP increased group, 30 patients $(57.7 \%)$ delivered preterm, 22 patients $(42.3 \%)$ had term.

It was found that increased levels of maternal serum CRP in early pregnancy were associated with increased incidence of preterm delivery. According to this study if the CRP value 1.5 the sensitivity will be $71.4 \%$ with specificity will be $86 \%$ to predict the preterm.

Neonatal complications like respiratory distress syndrome has no significant association with CRP levels. Of the total 42 preterm babies, 1 from Group A (8.3\%) and 12 from Group B (40\%) developed sepsis and were treated with IV antibiotics. There was statistically significant difference in development of neonatal sepsis between preterm infants of 2 groups. with infants born to increased CRP group there is increased chance of neonatal sepsis.

\section{CONCLUSION}

Elevated maternal serum CRP concentration in early second trimester was associated with increased incidence of preterm delivery and showed a positive correlation with neonatal sepsis.

\section{Funding: No funding sources Conflict of interest: None declared \\ Ethical approval: Not required}

\section{REFERENCES}

1. Blencowe H, Cousens S, Oestergaard M, Chou D, Moller AB, Narwal R, et al. National, regional and worldwide estimates of preterm birth. The Lancet. 2012;379(9832):2162-72.

2. Yeast JD, Lu G. Biochemical markers for prediction of preterm labour. Obstet Gynaecol Clin North Am. 2005;32:369-81.

3. Dodds WG, Lams JD. Maternal C-reactive protein and preterm labour. J repord Med.2003;32:527-530.

4. Gewurz H, Mold C, Siegel J, Fiedel B. C-reactive protein and the acute-phase response. Year Book Medical Publishers 1982;345-71.

5. Haram K, Augensen K, Elsayed S. Serum protein pattern in normal pregnancy with special reference to acute-phase reactants. $\mathrm{Br} \mathrm{J}$ Obstet Gynaecol. 1983;90:139-45.

6. Palosuo T, Husman T, Koistinen J, Aho K. Creactive protein in population samples. Acta Med Stand. 1986;220:175-9. 
7. Bek KM, Nielsen FR, Qvist I, Rasmussen PE, Tobiassen M. C-reactive protein (CRP) and pregnancy. An early indicator of chorioamnionitis. A review. Eur J Obstet Gynecol Reprod Biol. 1990;35:29-33.

8. Tjoa ML, Van Vugt JM, Go AT, Blankenstein MA, Oudejans CB, Van Wijk IJ. Elevated C-reactive protein levels during first trimester of pregnancy are indicative of preeclampsia and intrauterine growth restriction. J Reprod Immunol. 2003;59:29-37.

9. Hvilsom GB, Thorsen P, Jeune B, Bakketeig LS. Creactive protein: a serological marker for preterm delivery? Acta Obstet Gynecol Scand. 2002;81:4249.

10. Ghezzi F, Franchi M, Raio L, Di Naro E, Bossi G, D'Eril GV, et al. Elevated amniotic fluid C-reactive protein at the time of genetic amniocentesis is a marker for preterm delivery. Am J Obstet Gynecol. 2002;186:268-73.

11. Abbassi-Ghanavati M, Greer LG, Cunningham FG. Pregnancy and laboratory studies: a reference table for clinicians. Obstet Gynecol. 2009;114(6):1326-31.

Cite this article as: Senthil S, Dhamayanthi S. Measurement of serum C-reactive protein levels in early second trimester as a predictor of preterm delivery. Int J Reprod Contracept Obstet Gynecol 2019;8:4946-50. 